\title{
Floristic Diversity of the Biodiversity Monitoring Plots and its Environs within Agata Mining Ventures, Inc., Tubay, Agusan del Norte, Philippines
}

\section{Roger T. Sarmiento}

College of Forestry and Environmental Sciences, Caraga State University, Ampayon, Butuan City, Caraga Region, Philippines

Study Area: Agusan del Norte, Philippines

Coordinates: $8^{\circ} 57^{\prime} \mathrm{N} ; 125^{\circ} 32^{\prime} \mathrm{E}$

Key words: Floral composition, Stand structure,

Nickel Mining, mine rehabilitation

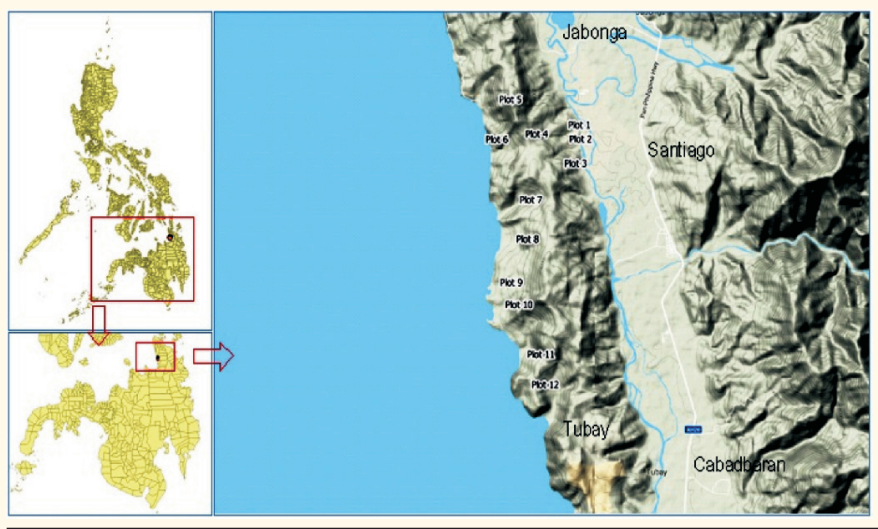

\section{Introduction:}

The Philippines is one of the top mineralized countries in the world for gold, nickel, copper, and chromite (Quintans, 2017; Kay, 2018). In the southern part of the country-the Caraga Region, nickel mining has been a promising industry (Sarmiento \& Demetillo, 2017) as 20 of the 48 registered metallic mines in the Philippines are found in the region and engaged in nickel mining (DENR-MGB, 2018). A number of these nickel mines were ordered shut down in early 2017 for several violations on environmental laws and resulted in the decline in nickel production worldwide. However, despite the issuance of closure orders, some companies continued to operate business as usual. Of the few law-abiding mining corporations in the region, Agata Mining Ventures, Inc. (AMVI) invested a substantial portion of its operational budget into research for crafting sound reforestation and rehabilitation plans. A good management plan guarantee sustainable use of existing natural resources such as soil, water, timber and biodiversity with the preparation and revision of this is a

\section{Abstract}

Woody plant species are key components of the forest ecosystem and are responsible for forest architecture and the overall composition of forest communities. On the established permanent biodiversity monitoring plots (PBMP) inside an approved mineral production sharing agreement areas in Agusan del Norte, the species diversity and abundance of trees were assessed wherein a total of 123 individuals of 16 families, 28 genera, and 37 species were recorded. Transect walks were likewise done to list existing flora within MPSA and recorded a total of 251 vascular plant species belonging to 80 families and 203 genera. The mineral lands of AMVI hold a tremendous diversity of species to include critically endangered Diospyros philippinensis and Camptostemon philippinense, among others. During re-assessment, it was observed that most of the monitoring plots progressed positively. At present, the biodiversity of these monitoring plots is under threat due to the anthropogenic and upcoming mining activities.

very crucial process, thus, appropriate knowledge on these resources is vital. However, during mining activities where mineral ores were extracted by means of the open-pit method, many biota having ecological and scientific importance were still displaced (Sarmiento et al., 2017).

Plant communities are the foundation for terrestrial trophic webs and animal habitats, and their structure and species composition are a cumulative result of biological and physical processes (Gates, 1993; Davis, 1981) that are difficult to measure directly. However, with the establishment of permanent monitoring plots the biodiversity resources can be monitored and its variation and function can be determined space-wise in time (Malabrigo et al., 2016). For this study, the main objective was to establish and maintain permanent biodiversity monitoring plots (PBMP) within the approved Mineral Production Sharing Agreement (MPSA) area of Agata Mining Ventures, Inc. in the province of Agusan del Norte. Specifically, it aimed to: i) determine the current composition and diversity of trees inside the established 
monitoring plots; ii) gather information on the abundance and conservation status of the different species inside monitoring plots; iii) generate a near-comprehensive list of the existing floral species within the approved MPSA area.

\section{Methodology:}

Permanent biodiversity monitoring plots: permanent biodiversity monitoring plots (PBMP) are the def ined areas to study various life forms that are geographically located and permanently gridded with markers (Malabrigo et al., 2016). The biodiversity resources inside PBMPs were monitored in place and time to determine variations structurally and functionally. The establishment of PBMPs will be very signif icant for monitoring long-term ecological research on biodiversity-functioning in relation to climate change and rehabilitation programs of any industry. A total of twelve (12) plots were established within the approved Mineral Production Sharing Agreement (MPSA) area of Agata Mining Ventures, Inc. (AMVI). Four (4) plots were located inside the active mining sites while the rest were outside but still within the approved MPSA area. The relative location of the permanent plots was recorded using a handheld GPS receiver taken on the southern left corner and plotted in a Google Earth (Map).

The sites were selected on the basis of previously conducted biodiversity surveys for AMVI. The comparison of information gathered from different periods can give a clearer picture of the dynamics of the ecosystem in time. The first fieldwork was conducted on June 6-9, 2017 for a series of activities such as i) the establishment of the PBMPs, ii) the initial assessment of existing flora species inside the monitoring plots, and finally iii) listing of other flora species outside monitoring plots but within the approved MPSA area. The second fieldwork was done on March 3-4, 2018 where the primary focus was to revisit and evaluate vegetation change and the diversity of species inside PBMPs. All tagged trees were assessed for presence/absence and other emerging tree species were recorded and noted.

Vegetation Sampling : the PBMPs were laid out with $20 \mathrm{~m}$ $\mathrm{x}$ 2om dimensions. A GPS receiver was used to determine the coordinates of the plot using the southern left corner as the reference point. All plants (trees in particular) inside the quadrat with $\mathrm{DBHH}>5 \mathrm{~cm}$ were measured and recorded. A fabricated aluminum tag bearing a numbered species code was then pinned on the visible section of the tree for identification and monitoring.

Transect walks and walkthroughs were likewise done to record other vascular plants outside PBMPs but within the approved MPSA area to generate a near-comprehensive listing of vascular species in the mineral areas of AMVI. Vascular plants are such plants that possess specialized conducting tissues, particularly xylem and phloem to include all flowering plants and conifers such as trees and other arborescent species, palms, herbaceous plants, vines to include woody and non-woody, as well as ferns. Species Identification and Nomenclature: identif ication of species was done on the field with the help of available literature. Some publications referring to the Philippine flora included Merrill (1912), Santos et al. (1986), Zamora and Co (1986), Madulid (2002), Primavera (2009) and online plant identification website PhytoImages (www.phytoimages.siu.edu/) were also utilized to compare photographed species. Some unfamiliar species were posted online through a social media group Co's Digital Flora of the Philippines (a public group of botanists, foresters, biologists and other plant enthusiasts) to confirm species identification. The scientific nomenclature and conservation status of species were crosschecked in the databases of The Plant List (www.theplantlist.org) and The IUCN Redlist of Threatened Species (www.iucnredlist.org), respectively.

Data analysis: it was encoded on a spreadsheet and analyzed using the vegetational analysis formula of density, relative density, frequency, relative frequency, dominance, relative dominance and the species importance value (SIV). The SIV was computed as the sum of the relative frequency, relative density and relative dominance of a species in a community or forest $(\mathrm{SIV}=\mathrm{RFreq}+\mathrm{RDom}+$ RDen). An SIV provides a better index than density alone regarding the importance or function of a species in habitat and also gives rank or order for a particular species within the community (Odum \& Barret, 2005). Ecological parameters such as Simpson?s Index of Diversity (1-D), Shannon-Wiener (H?) diversity index, and species richness, on the other hand, were computed using the PAST Statistical Software. Fernando scale was used to know the levels of biodiversity.

\section{Results and Discussion:}

General description of the area: the general ground formation inside active mining sites ranges from gently rolling to undulating to steep slopes alongside higher grounds. Dominant ground vegetation usually composed of dense formations of Bracken ferns (Pteridium aquilinium), Pako (Nephrolepis spp.), Nito (Lygodium flexuosum), Cogon grass (Imperata cylindrica) and other associated ground species. The first plot (Plot-1) was established on a small valley between two very steep slopes in Python Creek. The valley was made up of loose soil materials formed through deposition and sedimentation resulted from land conversion and massive mining operations on the upper elevations. The area was predominantly covered by ground vegetations whilst large trees were also found forming sparse tree patches along habitually moist portions of the intermittent creek. Some large trees observed include Antipolo (Artocarpus blancoi), Mango (Mangifera indica), Dita (Alstonia scholaris) and Narra (Pterocarpus indicus). However, the general 
vegetation canopy was composed of young growths typically still under the pole and sapling stage with $<30 \mathrm{~cm}$ $\mathrm{dbh}$ and reaching only 6-8 ft in height. Plots-2 \& 3 were similarly covered with dense ground vegetation of ferns and associated species. Plot-2 was located along E.morgado creek alongside the sloping terrain where the company's settling pond was constructed. Unlike the first plot, only a few tree species were found and mostly were planted for reforestation purposes. Accordingly, Mangium (Acacia mangium) were planted to start initial rehabilitation programs of the company, however, closer examination of the trees shows noticeably inferior growth in height and girth compared to its age. Plot-3, on the other hand, was purely dominated by ferns and only a single Kakaag (Commersonia bartramia) tree was found. The terrain was relatively flat and wide. Adjacent to it was active excavation and hauling activities, wherein expansion could possibly reach the established plot location in the near future.

Plot-4 can be described as a secondary growth forest where large diameter trees are still found naturally. It is located along Sua creek and can be considered adequately stocked and intact by simply looking on its canopy. Several hardwood species such as Ipil (Intsia bijuga) and Tindalo (Afzelia rhoimboidea) were encountered along the way together with natural fruit-bearing forest trees such as Bankoro (Morinda citrifolia), Antipolo (A.blancoi), and Marangbanguhan (A.odoratissimus) which can be a good food source of birds and other wildlife.

The other eight (8) PBMPs were established along the coastal zones. These plots were classified as secondary growth forest however; recent survey revealed that most of the areas were already converted into agricultural purposes. Plot-5 located in Barangay Lawigan was cleared for growing Falcata (Falcataria moluccana) along with Coconut (Cocos nucifera). Ground cover is clear and soil was so shallow, loose and rolling.

Plots-6, 7, 8, 9, 10 \& 12 were similarly utilized as coconut grooves. Though several saplings of forest tree species can be observed along transect walks and walk troughs, they were intentionally cleared and burnt to favor the growth of coconut. Plot-11, on the other hand, is unique among the other coastal plots established. It was located on a rocky cliff beside a small waterfall overlooking the seafront of SitioTagpangahoy. The area was relatively small yet has a number of different species that have been recorded, mostly fruit-bearing species. Ficus species such as Balete (F.balete) and Tangisangbayawak (F.variegata) were prolific food providers for bats, birds and other wildlife species.

Diversity of tree species inside PBMPs: a total of 37 species belonging to 28 genera and 16 families were found in the permanent plots. Of the 37 identified species, 34 were found to be indigenous to the Philippines and of which 9 were endemic or exclusively found only in the country.
Three exotic species were also found inside the permanent plots and these were Mangium (A.mangium), Coffe (Coffea arabica), and Falcata (F.moluccana). The genera of Ficus and Neonauclea have the most number of species present each having two species.

The study area was evidenced to fulfill the composite Shannon Weiner diversity index ( $\left.\mathrm{H}^{\prime}\right)$ of 3.10 which can be considered "High" based on the relative diversity scale developed by Fernando et al. (2009). Of all plots, Plot-1 has the highest index value of 2.31 followed by Plot 12 with an index value of 2.21 (Table-1). This can be attributed to the number of different species equally present within a plot with no single species being dominant. Plot-3, on the other hand, has no diversity value because only one single individual was found present on the plot.

\begin{tabular}{|c|c|c|c|c|}
\hline $\begin{array}{l}\text { PBMP No./ } \\
\text { Parameters } \\
\end{array}$ & $\begin{array}{l}\text { Species } \\
\text { Richness }\end{array}$ & $\begin{array}{l}\text { Number of } \\
\text { Individuals }\end{array}$ & $\begin{array}{l}\text { Simpson's } \\
\text { Index (1-D) }\end{array}$ & $\begin{array}{l}\text { Shannon's } \\
\text { Index (H') }\end{array}$ \\
\hline $\mathrm{PBMP}_{1}$ & 11 & 16 & 0.89 & 2.31 \\
\hline PBMP 2 & 3 & 6 & 0.50 & 0.87 \\
\hline $\mathrm{PBMP}_{3}$ & 1 & 1 & 0.00 & 0.00 \\
\hline $\mathrm{PBMP}_{4}$ & 9 & 12 & 0.83 & 2.02 \\
\hline PBMP 5 & 2 & 17 & 0.11 & 0.22 \\
\hline PBMP 6 & 2 & 6 & 0.44 & 0.64 \\
\hline $\mathrm{PBMP}_{7}$ & 2 & 8 & 0.22 & 0.38 \\
\hline PBMP 8 & 2 & 5 & 0.32 & 0.50 \\
\hline PBMP 9 & 4 & 9 & 0.62 & 1.15 \\
\hline PBMP 10 & 3 & 6 & 0.67 & 1.10 \\
\hline PBMP 11 & 9 & 19 & 0.84 & 1.98 \\
\hline PBMP 12 & 11 & 18 & 0.86 & 2.21 \\
\hline Cumulative & 37 & 123 & 0.93 & 3.10 \\
\hline
\end{tabular}

The most abundant species recorded was Coconut with 24 individuals followed by Falcata with 16. As classified beforehand, most of the established plots outside the active mine sites were located on agriculture converted areas where Coconut and Falcatawere primary planted as a commodity.

Stand and forest structure: a total of 123 individuals with a diameter at breast height of $5 \mathrm{~cm}$ or more were recorded from the 12 permanent plots. This account to a plot density of 256 stems per hectare or about 10 stems per $20 \mathrm{~m} \mathrm{x} 20 \mathrm{~m}$ plot only. The stocking is considered very low or "understocked" and therefore needs immediate attention by doing enrichment planting to enhance the number of trees especially along waterways.

Table-1: Number of individuals per diameter class inside PBMP's.

\begin{tabular}{lll}
\hline Diameter class & Diameter range & Number of plants \\
\hline Poles and Saplings & $<10 \mathrm{~cm}$ & 37 \\
Small trees & $10 \mathrm{~cm}$ to $<30 \mathrm{~cm}$ & 78 \\
Medium-size trees & $30 \mathrm{~cm}$ to $<60 \mathrm{~cm}$ & 8 \\
Larger trees & $>60 \mathrm{~cm}$ & 0
\end{tabular}

The forest is generally classified as a stand of "small trees" with an average diameter of only $16.2 \pm 1.5 \mathrm{~cm}$ for all 
trees inside plots. Moreover, there is a big difference in the proportion of the different diameter classes of the trees. More than $63 \%$ (78/123) of the individual trees fall under the category small trees while the medium-size trees account for only $6.5 \%$ (8/123) with no large trees recorded inside the plots. The rest were classified as poles and samplings at 30.1\% (37/123) as shown in Table-2. This variance can be attributed to the relatively young stand as older trees were cleared out due to mining activities if not converted into agricultural purposes. Trees with the largest diameter include F.variegata, A.rhomboidea, Diplodiscus paniculatus, and A.blancoi mostly found on beach forest patch in SitioTagpangahoy. A visual representation of the PBMPs was created using Stand Visualization Software (SVS) and image rendering was enhanced by employing vector tree images in the Microsoft PowerPoint environment (Fig.-1). The generated representations of all plots can be found in Table-2.

Floristic diversity of the MPSA: with transect walks and walkthroughs, a total of 251 vascular plants belonging to 203genera and 8ofamilies were encountered and identified. The dominant families with the most number of species enumerated were Fabaceae with 26 species, followed by Moraceae (16), Euphorbiaceae and Poaceae (both 13), and Malvaceae (12), while for the genera were Ficus (with 9 species), Artocarpus (6) and Cyperus (5). The top ten families with the most number of species encountered and identified were presented in Fig.-1 while the full list of encountered species can be found in Table- 5 .

Based on growth habit, more than $54 \%$ of the identified species were classified as trees and other arborescent species, $24 \%$ were accounted as herbaceous species (annuals and perennials), 9\% were shrubs, $5 \%$ for vines both woody and non-woody, while palms and palmlike species (4\%), as well as ferns and fern allies (4\%), comprise only a small portion of the entire flora Fig.-1.

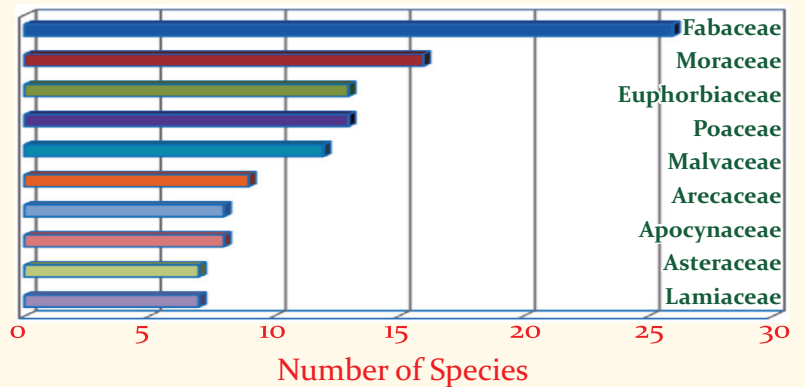

Figure-1: Top ten families with the most number of species encountered and identif ied in the MPSA

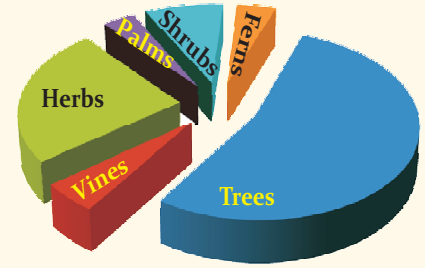

Figure-2: Percentage distribution of vascular plants found within the MPSA according to theirgrowth habit.
Table-3: Distribution of species as per IUCN Conservation Status.

\begin{tabular}{lll}
\hline IUCN Category & Number of Species & Percent \\
\hline NotAssessed & 199 & $79 \%$ \\
Least Concern & 26 & $10 \%$ \\
Vulnerable & 12 & $5 \%$ \\
Lower Risk & 7 & $3 \%$ \\
Data Deficient & 3 & $1 \%$ \\
Endangered & 2 & $1 \%$ \\
NearThreatened & 2 & $1 \%$ \\
Totals & 251 & $100 \%$ \\
\hline
\end{tabular}

Table-4: Notable changes observed in the monitoring plots

PBMPNo. Changes observed

1 Tagged trees were still present; however, the ground elevation was slightly altered by the accumulation of sediments from the recently constructed roadway in the upper elevation North side of the plot. Ground vegetations such as Bracken fern and Cogon have grown denser than the previous visit.

2 Tagged trees were still present and no significant change was observed except for the rapid growth of Bracken ferns on the ground.

3 The entire plot was already mined out and the solitary tagged tree was already gone.

4 About 2 tagged trees were felled and ground vegetations were cleared due to expansion of rubber plantation from the upper elevation.

5 All tagged trees were still present and no significant change was observed. The ground cover is still open since the area was utilized for growing $\mathrm{F}$. moluccana.

6 All tagged trees were still present and no significant change was observed except for the continuous growth of ground vegetation such as Talahib and Cogon.

7 All tagged trees still present and new emergent species were recorded such as F. gigantifolia and Musa sppwhich were not found on the previous visit. The ground vegetation has grown much thicker; however, the threat of being cleared is high since quarrying operation for limestone was active in the adjacent area.

8 All tagged trees still present and no significant change was noted. Ground was cleared as the previous visit since the area was utilized for growing $\mathrm{C}$. nucifera.

9 Two of the tagged trees were cut, however new trees have grown as coppice. The stand has grown denser and access trails were already covered.

10 Tagged trees were still present and new trees were recorded. The stand was composed of thick juvenile trees during the previous visit and now the trees have grown larger than before.

11 All tagged trees were present and no significant change was observed. The plot location was hard to accessible thus no sign of disturbance was noted.

12 Three of the tagged trees were cut and 2 coppiced. Stand has grown thicker as ground vegetation becomes denser.

Ecologically important species: about sixteen (16) species recorded from the area are listed threatened under the IUCN Red List of Threatened Species (IUCN 2017). Noteworthy among the list, Kamagong (Diospyros philippenensis) and Gapas-gapas (Camptostemon philippinense) were the critically endangered species. Other threatened species categorized as "Vulnerable" include Molave (Vitex 


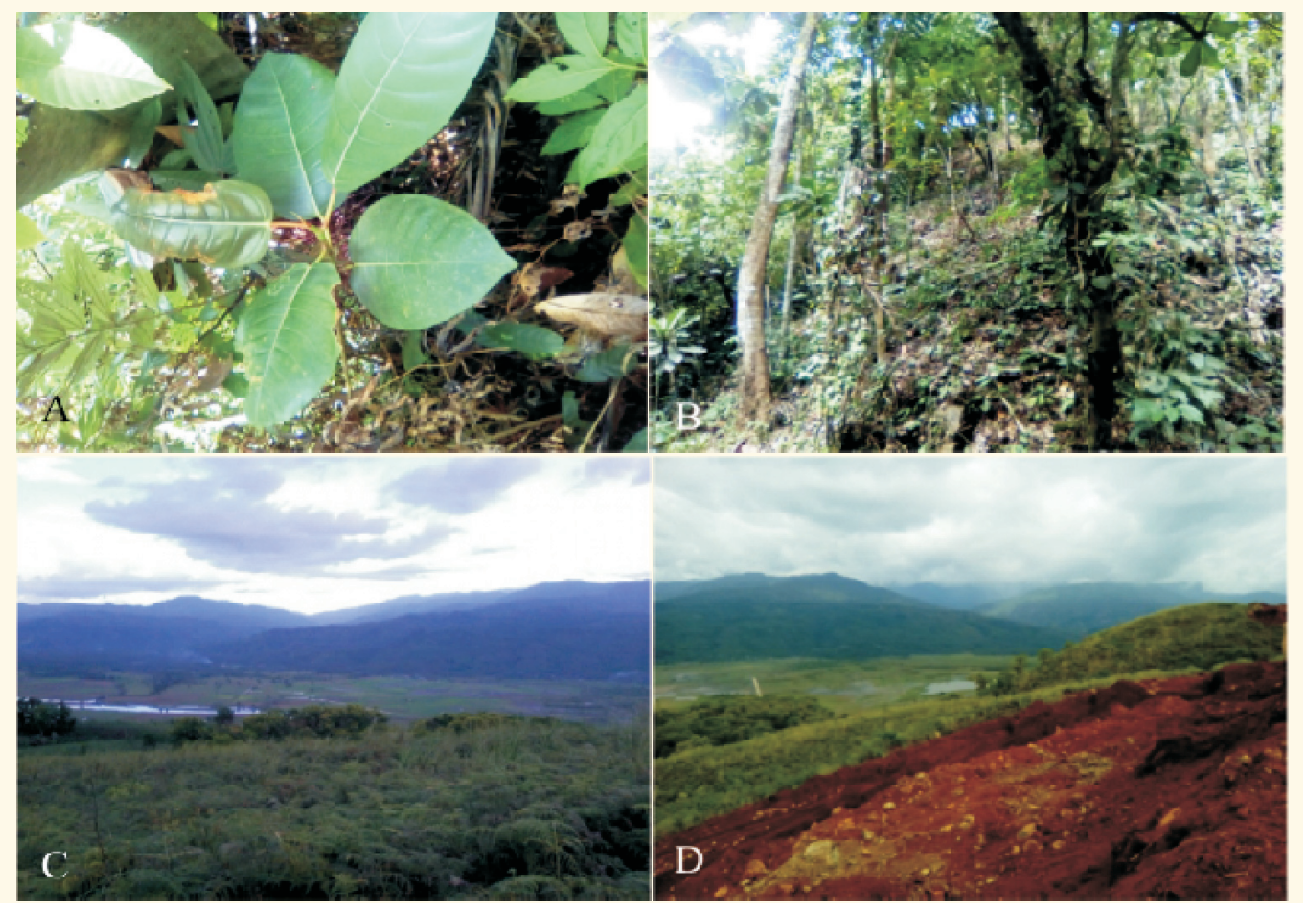

Figure-3: Observed changes in the PBMPs inside AMVI-MPSA area. A) Emergent species F.gigantifolia in Plot-7; B) Cleared ground vegetation in Plot-4 for Rubber farm expansion; C) Plot-3 taken June 2017, D) Plot-3 taken March 2018.

parviflora), Tindalo (A.rhomboidea), Ipil (I.bijuga), Anislag (Securinega flexuosa), Balobo (Diplodis cuspaniculatus), Hamindang (Macaranga bicolor) and Antipolo (A.blancoi) among others.

Species are classified by the IUCN Red List into nine groups, specified through criteria such as rate of decline, population size, area of geographic distribution, and degree of population and distribution fragmentation. Table-3 shows the distribution of identified species according to IUCN groups where largely are categorized under "NOT ASSESSED" category. Only $6 \%$ of the identified species (Vulnerable and Endangered) are classif ied as threatened.

\section{General observation of PBMPs during reassessment:} the 12 PBMPs were revisited on March 2018 to reassess the conditions of the stand and the existing flora species therein. The tagged trees were checked (presence/absence) as well as emerging species were noted on the data tally. Changes in the general form of the stand whether cleared, disturbed or mined out were likewise noted. After a 9month elapsed period from the first survey, it was observed that the majority of the PBMPs experienced significant changes either naturally or artificially. The following notes illustrate the observed changes on the stands.

\section{Conclusion:}

The effort of management on biodiversity has become a major consideration for resource managers (Burton et al., 1992) especially in mining industries where subsequent operations likely cause adverse impacts on the ecosystem.
Biodiversity is necessary to make ecosystem healthy (Naidu, 2016) and which is difficult to measure directly (Davis, 1981). With the establishment of PBMPs in the mineral land of AMVI, biodiversity resources can be monitored effectively on time. The results of the recent survey showed that the MPSA of AMVI holds a remarkable diversity of trees and other vascular species in contrast to most serpentine areas (Weerasinghe et al., 2016).

The monitoring plots in coastal areas of MPSA were already converted into agriculture purposes and therefore prone to physical and anthropological disturbances, whilst those inside active mining sites were affected by management developmental activities. After a 9-month elapsed period, most of the plots were noted with significant changes structurally and physically. The documentation of these patterns such as tree diversity and their distribution provides a good database, useful for management measures on the remaining resources.

\section{Acknowledgments:}

The author would like to express gratitude to the management and staff of Agata Mining Ventures, Inc. for funding and logistics of this research. 
Table-5: List of encountered vascular species in the MPSA of Agata Mining Ventures, Inc.

\begin{tabular}{|c|c|c|}
\hline No. Family Name & Scientific Name & Common Name \\
\hline \multicolumn{3}{|c|}{ Ferns and Fern allies } \\
\hline $\begin{array}{l}1 \text { Adiantaceae } \\
\text { Maidenhair }\end{array}$ & Adiantum capillus- $v$ & $\mathrm{C}$ o $\mathrm{m} \mathrm{m}$ o $\mathrm{n}$ \\
\hline
\end{tabular}
3
Alocasia macrorrhizos

Caladium bicolor

Colocasia esculenta

Cyrtosperma merkusii

Dieffenbachia amoena

Syngonium hoffmannii

Sansevieriar oxburghiana

Ageratum conyzoides

Blumea balsamifera

Chromolaena odorata

Cosmos caudatus

Eclipta alba

Gerbera jamesonii

Wedelia biflora Wedelia

Impatiens balsamina

Ananas comosus

Cleome viscosa

Carica papaya

Cyperus digitatus

Cyperus flabelliformis

Cyperus iria

Cyperus rotundus

Jatropha curcas

Manihot esculenta

Phyllanthus niruri

Ricinus communis

Scaevolat accada

Hyptis suaveolens

Musa acuminata

Musa paradisiaca

Musa sapientum
Moradong Dilaw

Bastonni San Jose

Sagilala

Fragrant dracaena

Song of India

Urai

Urai Lalaki

Takip Kuhol

Biga

Gabi

Palawan

Bakya

Goosefoot

Buntot ng Tigre

Bulak-manok

Sambong

Hagonoy

Cosmos

Tuhod-manok

African daisy

Kamantigi

Pinya

Apoy-Apoyan

Papaya

Balayang

Umbrella plant

Gumi

Tarugog

TubangBakod

Cassava

Sampasampalukan

Castor Oil Plant

Beach cabbage

Suag-kabayo

Sagingmatsing

Sagingsaba

Saging
Corazon de Maria

41 Poaceae
42
43
44
45
46

47

48

49

50

51

52

53

54 Pontederiaceae

55 Solanaceae

56 SphaenocleaceaeS

57 Zingiberaceae

58

59

60

\section{Palms}

1 Arecaceae

2

4

5

5
6

7

8

9

Shrubs

Apocynaceae

2 Asclepiadaceae

3 Euphorbiaceae

Fabaceae

5

6

7

8

9

10

11

\section{Malvaceae}

13

14 Nyctaginaceae

15 Ochnaceae

16 Rubiaceae

17

18 Solanaceae

19 Thymelaeaceae 2o Verbenaceae

\begin{tabular}{|c|c|}
\hline 21 & Duranta repens \\
\hline 22 & Lantana camara \\
\hline \multicolumn{2}{|c|}{ Trees and Arborescent species } \\
\hline 1 Anacardiaceae & Buchanania arborescens \\
\hline 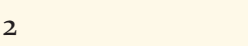 & Buchanania nitida \\
\hline 3 & Mangifera altissima \\
\hline 4 & Mangifera indica \\
\hline 5 & Rhusta itensis \\
\hline
\end{tabular}

Arundo donax Tambo

Bambusa vulgaris Kawayangkilig

Chyrosopogonaciculatus Amorseco

Cymbopogon citratus Tanglad

Dendrocalam usmerrilianus Bayog

Digitariaciliaris Crabgrass

Imperata cylindrica Cogon

Oryzasativa Rice

Paspalum conjugatum Kulape

Pennisetum polystachyonBuntot-pusa

Saccharum officinarum Sugarcane

Saccharum spontaneum Talahib

Zeamays Mais

Eicchomia crassipes Water hyacith

Solanum torvum Talong-talongan

Mais-mais

Alpinia zerumbet Red ginger

Costus speciosus Spiralginger

Etlingeriaelatior Torchginger

Hedychium coronarium Camia

Areca catechu Bunga

Arenga pinnata Kaong

Calamus spp. Rattan

Caryotacumingii Pugahan

Cocos nucifera* Niog

Dypsislutescens Palmera

Heterospathe elata Saguisi

Metroxylonsagu Sago

Nypafruticans Nipa

Ervatamiadivaricata Pandakaki

Calotropisgigantea Kapal-kapal

Phyllanthus reticulatus Malatinta

Caesalpiniapulcherrima Caballero

Cassia occidentalis Balatongaso

Desmodiumpulchellum Payang-payang

Desmodium umbellatum Mani-mani

Mimosa invisa Aroma

Mimosapudica Makahiya

Puerariaphaseoloides Kudzu

Sidarhombifolia Walis-walisan

Hibiscus rosa-sinensis Gumamela

Urenalobata Kollo-kollot

Bougainvillea spectabilis Bougainvillea

Ochnaserrulata Bird's Eye Bush

Ixorachinensis Santan

Mussaendaphilippica Kahoidalaga

Capsicumfrutescens Sili

Wikstroemia indica Salagongliitan

Clerodendrum qudriloculare

Bagauakna pula

Duranta

Coronitas

Balinghasai

Anitap

Pahutan

Mango

Bino 


\begin{tabular}{|c|c|c|c|c|c|c|}
\hline 6 & & Semecarpus cuneiformis & Ligas & 61 & Premna odorata & Alagau \\
\hline 9 & \multirow{2}{*}{ Annonaceae } & Annona reticulata & Anonas & 64 & Vitex trifolia & LagundingDagat \\
\hline 11 & & Polyalthia oblongifolia & Lapnisan & 66 & Neolitse avidalii & Puso-puso \\
\hline 12 & \multirow{4}{*}{ Apocynaceae } & Alstonia angustiloba & Silhigan & 67 Lecythidaceae & Barringtonia acutangula & Himbabalud \\
\hline 13 & & Alstonia macrophylla & Batino & 68 & Barringtonia asiatica & Botong \\
\hline 16 & & Plumeria acuminata & Calachuchi & 71 Lythraceae & Lagerstroemia speciosa & Banaba \\
\hline 17 & & Voacangaglobosa & Bayag-usa & 72 Malvaceae & Colona serratifolia & Anilao \\
\hline 18 & Araliaceae & Polyscias nodosa & Malapapaya & 73 & Commersoni abartramia & Kakaag \\
\hline 19 & Bixaceae & Bixa orellana & Achuete & 74 & Diplodiscus paniculatus & Balobo \\
\hline 20 & Bombacaceae & \multicolumn{2}{|c|}{ Camptostemon philippinense } & 75 & Heritiera littoralis & Dungon-late \\
\hline 23 & Casuarinaceae & Casuarina equisetifolia & Agoho & 80 & Pterospermum diversifoliu & im \\
\hline \multirow[t]{2}{*}{24} & & \multicolumn{3}{|c|}{ Gymnostoma rumphianum } & & Bayok \\
\hline & & & Agoho del Monte & 81 & Theobroma сасао & Cacao \\
\hline 25 & Celastraceae & Euonymusjavanicus & Malasangki & 82 Meliaceae & Melia dubia & Bagalunga \\
\hline 26 & Clusiaceae & Calophyllum blancoi & Bitanghol & 83 & Sandoricum koetjape & Santol \\
\hline 27 & & Calophyllum inophyllum & Bitaog & 84 & Swieteniam acrophylla & LL Mahogany \\
\hline 28 & & Cratoxylum formosum & Salinggogon & 85 & Xylocarpus moluccensis & Piagau \\
\hline 29 & & Cratoxylum sumatranum & Paguringon & 86 Moraceae & Artocarpus blancoi & Antipolo \\
\hline 30 & & Garcinia venulosa & Gatasan & 87 & Artocarpus communis & Kamansi \\
\hline 31 & Combretaceae & Terminalia catappa & Talisai & 88 & Artocarpush eterophylla* & Nangka \\
\hline \multirow[t]{2}{*}{32} & \multirow{2}{*}{\multicolumn{2}{|c|}{ DipterocarpaceaeAnisoptera mindanensis }} & Mindanao & 89 & Artocarpus odoratissimus & Marang \\
\hline & & & Palosapis & & & Banguhan \\
\hline \multirow[t]{2}{*}{40} & & \multicolumn{2}{|c|}{ Melanolepism ultiglandulosa } & 97 & Ficus odorata & Pakiling \\
\hline & & & Alim & 98 & Ficus psuedopalma & Niog-niogan \\
\hline 41 & & Securineg aflexuosa & Anislag & 99 & Ficus septica & Hauili \\
\hline 42 & Fabaceae & Acacia auriculiformis & Auri & 100 & Ficus variegata & Tangisang \\
\hline 43 & & Acacia mangium & Mangium & & & bayawak \\
\hline 44 & & Adenantherap avonina & Malatanglin & 101 & Streblus asper & Kalios \\
\hline 45 & & Afzeliarhom boidea & Tindalo & 102Moringaceae & Moringa oleifera & Malunggay \\
\hline 46 & & Archidendrons cutiferum & Anagap & 103 Myricaceae & Myrica javanica & Hindang \\
\hline 47 & & Cassia fistula & Golden shower & 104Myrsinaceae & Aegiceras corniculatum & Saging-saging \\
\hline 48 & & Erythrina orientalis & Dapdap & 105 & Ardisias quamulosa & Tagpo \\
\hline 49 & & Falcatariam oluccana & MoloccanSau & 106 Myrtaceae & Eucalyptus deglupta & Bagras \\
\hline 50 & & Gliricidia sepium & Kakawate & 107 & Leptospermum amboinens & \\
\hline 51 & & Intsiabijuga & Ipil & & & Payuspos \\
\hline 52 & & Leucaena leucocephala & Ipil-ipil & 108 & Psidium guajava & Bayabas \\
\hline 53 & & Ormosiacalavensis & Bahai & 109 & Syzygium myrtifolium* & Red lip tree \\
\hline 54 & & Pongamiapinnata & Bani & 110 & Syzygium samarangense & Macopa \\
\hline 55 & & Pterocarpus indicus & Narra & 111 & Syzygium spp & Sagimsim \\
\hline 56 & & Tamarindus indica & Sampalok & 112 & Xanthostemon verdugonia & anus \\
\hline 57 & Flacourtiaceae & Casearia fuliginosa & Talitan & & & Mangkono \\
\hline 58 & Hernandiaceae & Hernandia ovigera & Koron-koron & 113 Olacaceae & Strombosia philippinensis & \\
\hline 59 & Lamiaceae & Gmelina arborea & Yemane & & & Tamayuan \\
\hline 60 & & Premnain tegrifolia & AlagauDagat & 114 Oxalidaceae & Averrho abilimbi & Kamias \\
\hline
\end{tabular}




\begin{tabular}{|c|c|c|}
\hline 115 Pandanaceae & Pandanus tectorius & Pandandagat \\
\hline 116 Pittosporaceae & Pittosporum pentandrum & Mamalis \\
\hline 117 Rhizophoraceae & Ceriop stagal & Tangal \\
\hline 118 & Rhizophora mucronata & Bakauanlalake \\
\hline 119 Rubiaceae & Morinda citrifolia & Bangkoro \\
\hline 120 & Nauclea orientalis & Bangkal \\
\hline 1 & Neonauclea bartlingii & Lisak \\
\hline 122 & Neonauclea media & Wisak \\
\hline 123 Rutaceae & Citrus grandis & Pomelo \\
\hline 124 & Citrus madurensis & Kalamansi \\
\hline 5 & Clausena brevistyla & Kalomata \\
\hline 126 & Evodia confusa & Bugauak \\
\hline 127 & Evodia monophylla & $\begin{array}{l}\text { Kamal } \\
\text { bugtongin }\end{array}$ \\
\hline 128 Santalaceae & Exocarpos latifolius & Tulisan \\
\hline 129 Sapindaceae & Guioakoel reuteria & Alahan \\
\hline 130 Sapotaceae & Chrysophyl lumcainito & Kaimito \\
\hline 131 & Pouteria rivicoa & Tiesa \\
\hline 132 Ulmaceae & Trema orientalis & Anabiong \\
\hline 133 Urticaceae & Leucosyke capitellata & Alagasi \\
\hline 134 & Pipturus arborescens & Dalunot \\
\hline \multicolumn{3}{|c|}{ Vines and other scandent species } \\
\hline 1 Apocynaceae & Dischidia major & Lobo-lobo \\
\hline Convolvulaceae & Ipomoea pes-caprae & $\begin{array}{l}\text { Beach morning } \\
\text { glory }\end{array}$ \\
\hline 3 & Ipomoea batatas & Camote \\
\hline 4 & Merremiapeltata & Burakan \\
\hline \multirow[t]{2}{*}{ Dioscporeaceae } & Dioscore a alata & Ubi \\
\hline & Dioscore ahispida & Nami \\
\hline \multirow[t]{2}{*}{ Fabaceae } & Calopogonium mucunoide & \\
\hline & & Nipay-nipay \\
\hline 8 & Centrosem apubescens & Centro \\
\hline 9 & Clitoriat ernatea & Pukinggan \\
\hline Flacourtiaceae & Flagellaria indica & Baling-uai \\
\hline Pandanaceae & Freycinetia maxima & Pandan-baging \\
\hline Passifloraceae & Passiflor afoetida & Kurombot \\
\hline 13 Piperaceae & Piper betle & Buyo \\
\hline
\end{tabular}

\section{References:}

Burton, P.J., Balisky, A.C., Coward, L.P., Cumming, S.G. \& Kneeshaw, D.D. (1992): The value of managing for biodiversity. Forest. Chron., 68(2):225-237.

Davis, M.B. (1981): Quaternary history and the stability of forest communities, pp. 132 -153 in D.C. West \& H.H. Shugart (eds.) Forest succession: concepts and application. Pub. By: Springer-Verlag, New York.
DENR-MGB. (2018): Mining Industry Statistics. Pub. By: Department of Environment and Natural Resources Mines and Geo-Sciences Bureau (http://www.mgb.gov.ph/).

Kay, A. (2018): 10 Top countries for nickel production. Nickel Investing News. https://investingnews.com/daily/ resource-investing/base-metals-investing/nickelinvesting/10-top-nickel-producing-countries/

IUCN (2018): The IUCN Red List of Threatened Species. Version 2018-1. http://www.iucnredlist.org.

Naidu, M.T. \& Kumar, O.A. (2016): Tree diversity, stand structure, and community composition of tropical forests in Eastern Ghats of Andhra Pradesh, India. L. Asia-Pac. Biodiver., 9(3):328-334.

Nickrent, D.L., Costea, M., Barcelona, J.F., Pelser, P.B. \& Nixon, K. ( 2 o 0 o 6 ) : O n w a r d s. P h y t o I m a g e s . http://www.phytoimages.siu.edu.

Odum, E.P. \& Barret, G W. (2005): Fundamentals of Ecology. Fifth Edition.Pub. by: Belmont, CA : Thomson Brooks/Cole, Singapore, 068808.

Primavera, J.H. (2009): Field guide to Philippine mangroves. Pub. By: Philippine Tropical Forest Conservation Foundation, Inc. and the Zoological Society of London. P-40.

Primavera, J.H., Sadaba, R.B., Lebata, M.J.H.L. \& Altamirano, J.P. (2004): Handbook of Mangroves in the Philippines Panay. Pub. By: Aquaculture Department, Southeast Asian $\mathrm{F}$ i s h e ri e s D e v e lo p m e n $\mathrm{t}$ e $\mathrm{nt}$ e $\mathrm{r}$. http://hdl.handle.net/10862/3053

Quintans, J.D. (2017): Mining industry in the Philippines. The Manila Times. https://www.manilatimes.net/miningindustry-philippines/348610/

Sarmiento, R.T. \& Demetillo, M. (2017): Rapid assessment on tree diversity of nickel mining sites in Carrascal, Surigao del Sur, Philippines.J. Biodiver. Environ. Sci., 10(4):2222-3045.

Sarmiento, R.T., Garcia, G.A.A. \& Varela, R.P. (2017): Diversity of the riparian vegetation of lower Agusan river towards establishing the sago-based eco-belt for disaster risk reduction. J. Biodiver. Environ. Sci., 10(4):70-80. 